\title{
DFT Conformational Study of Calix[6]arene: Hydrogen Bond
}

\author{
Kwangho Kim and Jong-In Choe \\ Deparment of Chemistry, Chung-Ang Lniversit, Seoul 156-756. Korea. ${ }^{*}$ E-mail: choejiacau ac.kn \\ Received January 20, 2009, Accepted February 21, 2009

\begin{abstract}
We have performed DFT calculations to investigate the conformational characteristics and hydrogen bonds of the calix[6]arene (1) and p-tert-butylcalix[6]arene (2). The structures of various conformers of 1 were optimized by using the B3LYP/6-3 IG(d,p) and /6-31+ $\mathrm{i}(\mathrm{d}, \mathrm{p})$ methods followed by single point calculation of MPWIPW91/ $6-31 \mathrm{G}(\mathrm{d}, \mathrm{p})$. The relative stability of the confonmers of 1 is in the following order: cone (pinched: most stable) $>$ partial-cone $>$ cone (winged $) \sim 1,2$-altemate $\sim 1,2,3$-alternate $>1,4$-altemate $>1,3$-altemate $>1,3,5$-altemate. The structures of different conformers of 2 were optimized by using the B3LYP/6-31G(d,p) method followed by single point calculation of MPW1PW9l/6-3lG $(\mathrm{d}, \mathrm{p})$. The relative stability of the conformers of 2 is in the following order: cone $($ pinched $)>1,2$-alternate $>$ cone $($ winged $)>1,4$-altemate $\sim$ partial-cone $>1,2,3$-alternate $>1,3,5$ altemate $>$ $\mathbf{1 , 3}$-altemate. One of the important factors affecting the relative stabilities of the various conformers of the $\mathbf{1}$ and $\mathbf{2}$ is the number and strength of the intramolecular hydrogen bonds
\end{abstract}

Key Words: DFT. MPW 1PW91, Calix[6]arene. Conformer. Hydrogen bond

\section{Introduction}

Calixarenes having four, six, or eight repeating units are well studied among the varying structures of calix[n]arenes. Calix[4]arenes have proven to be useful building blocks in supramolecular chemistry. because of the possibility of selective functionalization and control over the conformation. The selective functionalization of calix[6]arenes has been explored. ${ }^{3}$ but in contrast to calix[4]arenes. it is difficult to immobilize the conformations of calix[6]arenes.

Intramolecular hydrogen bond formation determines the stability of conformations of unsubstituted calix[n]arenes. ${ }^{3}$ The conformational characteristics of calix[6]arene were studied by using the molecular mechanical method. ${ }^{4}$ The most stable conformation of calix[6]arenes ( $1^{5}$ and $2^{65}$ ) (Chart 1 ) in the solid state is called a pinched cone because two methylene bridges are pointing into the cavity (Figures $\mathrm{I}(\mathrm{a})$ and $2(\mathrm{a})$ ). The skeleton of calix[6]arene is pinched to allow for a circular array of six hydrogen bonds. Early measurements by Gutsche et al. with ${ }^{l} \mathrm{H}$ NMR spectroscopy have shown that in solution p-tert-butylcalix[6]arene $\mathbf{2}$ is conformationally flexible. ${ }^{\text {3a }}$ From the coalescence of the methylene hydrogens. they postulated the interconversion of two equivalent cone conformations. Molins et al. ${ }^{8}$ published a sophisticated 2D NMR study of upper rim substituted trichlorocalix[6]arene. Their conformation is described as a winged cone. with four aryl groups in up alignment and two aryl groups located at opposite sites bent outside (Figures 1(c) and 2(c)). All six methylene bridges are pointing outward. The findings of Molins $e t$ al. have been disputed by Reinhoudt group. ${ }^{9}$ This group claimed that the pinched cone found in the solid state is also the conformation in solution.

Recently we have reported the $D F T$ calculation results for the conformers and hydrogen bondings of $t$-buty lcalix[5] arene (3). $t$-butylcalix[4]arene (4) and monomethoxycalix[5]arene. ${ }^{10.11}$ The first objective of this research is to determine the relative stability of different conformational isomers for calix-

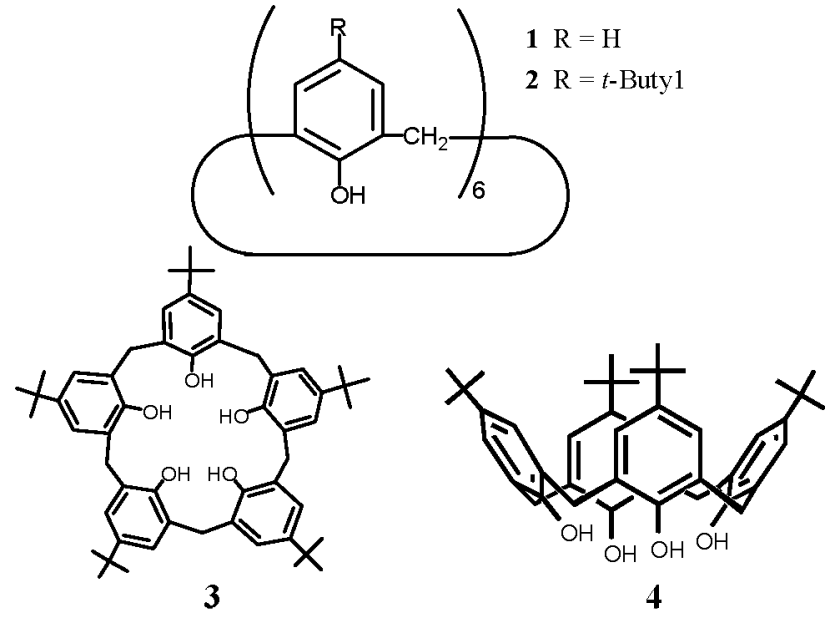

Chart 1. Chemdraw structures of calix[6]arene (1), p-tert-butylcalix [6] arene ( 2$), p$-ten-buty lcalix[5] arene (3) and the cone conformer of $p$-ten-butylcalis[4]arene (4).
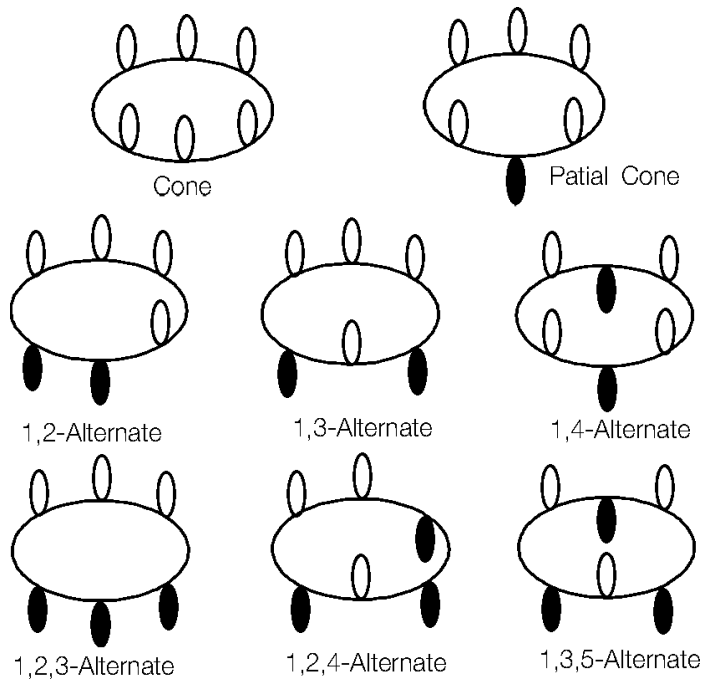

Chart 2. The sketches of the eight conformations of calis[6]arene. 
[6]arene (1) and p-tert-butylcalix[6]arene (2) by using the $D F T$ calculation. The second objective is to investigate the intramolecular hỵdrogen bonds bỵ the hỵdroxyl groups of the 1 and 2 .

\section{Computational Methods}

The initial pinched cone-type structures of the calix[6]arene (1) and p-tert-butylcalix[6]arene (2) were obtained from Cambridge Structure Database (CSD ${ }^{\text {1a }}$ entry NOB$\mathrm{LEV}^{\text {lab }}$ (1) and $\mathrm{KENBUA}^{\mathrm{lac}}(2)$ ), and other conformations are constructed by using the molecular mechanics (MM), molecular dynamics (MD), and AMl calculations of HyperChem. ${ }^{13}$ In order to find the optimized conformers. we executed a conformational search by using a simulated annealing method. which has been described in a previous publication. ${ }^{14}$ The conformational isomers of 1 and 2 obtained from the MM/MD and AMl semi-empirical calculations were fully re-optimized by using the $D F T$ methods to determine the relative energies and the structures of eight distinct conformations in Chart 2. The level of theory used was Becke's three-parameter exchange functional in combination with the nonlocal correlation functional of Lee, Yang, and Parr (B3LYP) ${ }^{15,16}$ and the 6-3 IG(d.p) basis set. Consecutive B3LYP/6-3IG(d.p) and B3LYP/6-31+G(d,p) optimizations followed by single point calculation of MPW IPW91/6-3 IG(d.p) using Gaussian $03^{17}$ were performed.

\section{Results and Discussion}

It is well known that the p-tert-butylcalix[5]arene (3) and p-tert-butylcalix[4]arene (4) form strong intramolecular hydrogen bonds among $\mathrm{OH}$ groups and represent the cone conformer as the most stable structure among four conformations (cone. partial cone. 1.2-alternate and 1,3-alternate). ${ }^{4}$

The possible conformations of calix[6]arene (1) and p-tertbutylcalix[6]arene (2) are cone (pinched or winged), partial cone, 1,2-altemate. 1,3-alternate. 1,4-alternate, 1,2,3-alternate. 1.2.4-altemate. and 1,3.5-altemate. The DFT optinizations without any constraint were carried out for the distinct conformers of the 1 and 2, respectively.

Table 1 shows the total and relative energies of the conformers of calix[6]arene (1) calculated by the DFT B3LYP/6$31 \mathrm{G}$ (d.p), B3LYP/6-31+G(d.p) and MPW $1 P W 91 / 6-31 \mathrm{G}(\mathrm{d}, \mathrm{p})$ calculations. consecutively. During the $D F T$ optimization of 1.2.4-altemate conformation, this structure spontaneously changed to the most stable pinched cone. Therefore. the energy of the 1.2,4-altemate conformer is onitted in Tables 1 and 2 . The relative stabilities of $\mathrm{B} 3 \mathrm{LYP} / 6-31+\mathrm{G}(\mathrm{d} . \mathrm{p})$ calculation results of 1 are in the following order: cone (pinched: most stable) $>$ partial-cone $>$ cone (winged $) \sim 1.2$-altemate $\sim 1.2 .3$ alternate $>1.4$-alternate $>1,3$-alternate $>1,3,5$-alternate

We also report the calculated results of the DFT B3LYP/ 6-3IG(d.p) and MPWIPW9I/6-3IG(d.p) calculations for the conformers of $p$-tert-butylcalix[6]arene (2). The B3LYP/6-31+G

Table 1. DFT Calculated Energies ${ }^{a}$ of the Various Conformers of 1

\begin{tabular}{|c|c|c|c|c|c|c|c|c|}
\hline Confonnes & $\begin{array}{c}\text { cone } \\
\text { (pinched) }\end{array}$ & $\begin{array}{c}\text { cone } \\
\text { (winged) }\end{array}$ & $\mathrm{pc}$ & $12 a$ & $13 a$ & l4á & $123 a$ & 135 \\
\hline $\begin{array}{c}\text { B3LYP } \\
/ 6-\hat{3} \mathrm{lG}(\mathrm{d}, \mathrm{p})^{r}\end{array}$ & -2073.6287 & -2073.6046 & -2073.6098 & -2073.6036 & -2073.5935 & -2073.5973 & -2073.6030 & -2073.5849 \\
\hline$\Delta E^{d}$ & 0.00 & 15.14 & 11.85 & 15.75 & 22.11 & 19.72 & 16.12 & 27.48 \\
\hline $\begin{array}{c}\text { B3LYP } \\
/ 6-31+G\left(d_{1} p\right)^{r}\end{array}$ & -2073.6982 & -2073.6762 & -2073.6817 & -2073.6761 & -2073.6687 & -2073.6698 & -2073.6766 & -2073.6609 \\
\hline$\Delta E^{d}$ & 0.00 & 13.80 & 10.37 & 13.87 & 18.55 & 17.81 & 13.59 & 23.44 \\
\hline $\begin{array}{l}\text { MPWIPW91 } \\
/ 6-31 G(d, p)^{\circ}\end{array}$ & -2073.1652 & -2073.1419 & -2073.1480 & -2073.1416 & -2073.1324 & -2073.1347 & -2073.1407 & -2073.1254 \\
\hline$\Delta E^{d}$ & 0.00 & 14.65 & 10.79 & 14.83 & 20.58 & 19.15 & 15.40 & 25.02 \\
\hline
\end{tabular}

"The unit of DFT energy is in a.u. "Conformer: "pc" denotes partial cone. "12a" means 1,2-altemate, etc. (See Figure 1.) "Optimized Energy " $\Delta E$ (kcal mol) is the relative energy with respect to the most stable conformation (pinched cone). Error limits in these calculations are about $0.01 \mathrm{kcal}$ inol. "Single point energy: MPW1PW916-31G(d,p) B3LYP:6-31-G(d.p)

Table 2. DFT Calculated Energies" of the Various Conformers of 2

\begin{tabular}{|c|c|c|c|c|c|c|c|c|}
\hline Conformer $^{b}$ & $\begin{array}{c}\text { cone } \\
\text { (pinched) }\end{array}$ & $\begin{array}{c}\text { cone } \\
\text { (winged) }\end{array}$ & $\mathrm{pc}$ & $12 a$ & $13 a$ & $14 a$ & $123 \mathrm{a}$ & $135 a$ \\
\hline $\begin{array}{c}\text { B3LYP } \\
/ 6-31 \mathrm{G}(\mathrm{d}, \mathrm{p})^{r}\end{array}$ & -3017.2218 & -3017.1987 & -3017.1931 & -3017.2047 & -3017.1842 & -3017.1999 & -3017.1884 & -3017.1786 \\
\hline$\Delta E^{d}$ & 0.00 & 14.48 & 1803 & 10.72 & 23.58 & 13.77 & 20.99 & 27.12 \\
\hline $\begin{array}{l}\text { MPWIPW9I } \\
/ 6-3 / \mathrm{I}(\mathrm{d}, \mathrm{p})^{e}\end{array}$ & -3016.5551 & -3016.5340 & -3016.5287 & -3016.5402 & -3016.5148 & -3016.5290 & -3016.5232 & -3016.5173 \\
\hline$\Delta E^{d}$ & 0.00 & 13.27 & 16.58 & 9.37 & 25.32 & 16.41 & 2001 & 23.73 \\
\hline
\end{tabular}

absccsee the footnotes in Table 1. "Single point energy: MPW1PW916-31G(d,p): B3LYP:6-31G(d.p) 
(d.p) calculation of 2 was impossible to be completed with our computing resources. Table 2 shows the total and relative energies of the conformers of 2 . The relative stabilities of the MPW1PW91/6-31G(d.p) calculation results of 2 are in the following order: cone (pinched) $>1.2$-altemate $>$ cone ( $m$ inged $)>1.4$-alternate $\sim$ partial-cone $>1.2,3$-altemate $>1.3 .5-$ alternate $>1.3$-alternate.

One of the important factors affecting the relative stabilities of the various conformers of the calix[6]arenes is the number and strength of the intramolecular hydrogen bonds. The good stability of 1.2,3-altemate conformer of 1 among the less stable conformers can be explained by the four hydrogen bonds, whereas 1(1,3-altemate) has three $H$-bonds and 1(1.3.5-alternate) has none. We will explain the characteristics of the hydrogen bonds in various conformers later in

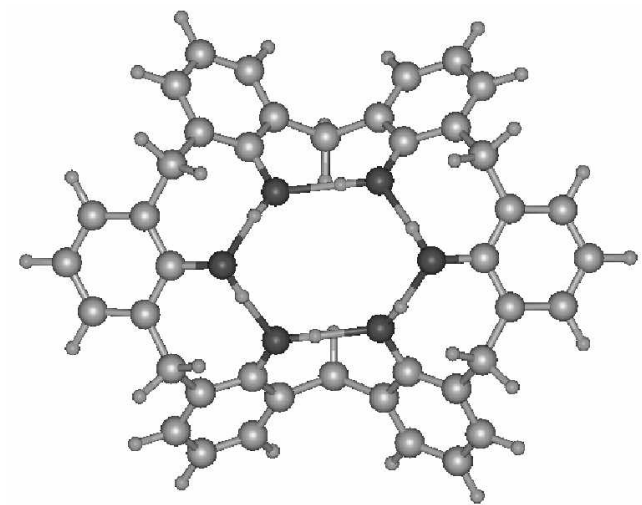

(a) cone (pinched: botton view; PosMol)

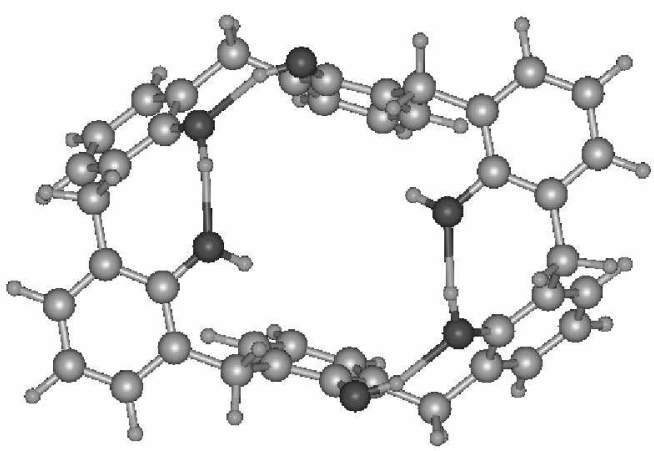

(c) cone (winged; PosMol)

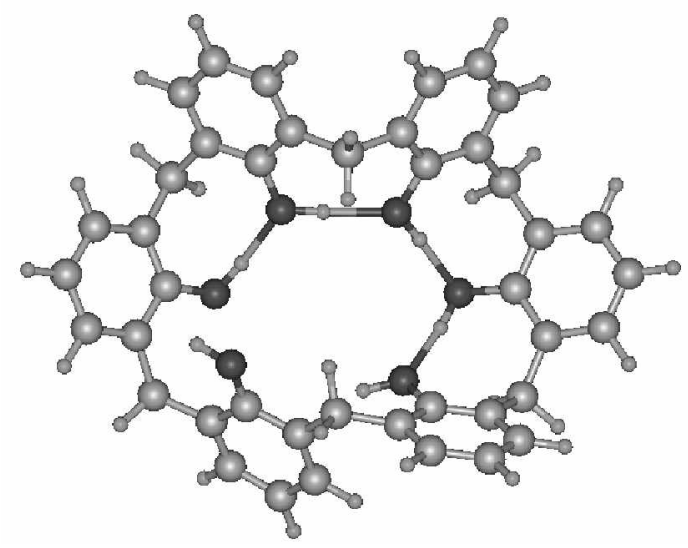

(e) partial-cone (PosMol) this section.

The MPW IPW91/6-3IG(d.p) calculated relative stabilities of the conformations of 1 in Table 1 suggest that the cone (pinched) conformer is $10.79 \mathrm{kcal} / \mathrm{mol}$ more stable than partialcone. about $15.0 \mathrm{kcal} / \mathrm{mol}$ more stable than cone (winged). 1.2-altemate and 1,2,3-alternate analogues. about $19.9 \mathrm{kcal} /$ mol more stable than 1.3-alternate and 1.4-alternate and $25.02 \mathrm{kcal} / \mathrm{mol}$ more stable than $1,3.5$-altemate, respectively.

However. The MPW1PW91/6-31G(d.p) calculated relative stabilities of the conformations of $\mathbf{2}$ in Table 2 suggest that the cone conformer is $9.37 \mathrm{kcal} / \mathrm{mol}$ more stable than 1.2 -alter nate. $13.27 \mathrm{kcal} / \mathrm{mol}$ more stable than cone (winged), about $16.5 \mathrm{kcal} / \mathrm{mol}$ more stable than 1,4 -alternate and partial-cone, $20.01 \mathrm{kcal} / \mathrm{mol}$ more stable than 1.2.3-altemate conformers. $23.73 \mathrm{kcal} / \mathrm{mol}$ more stable than 1.3 .5 -alternate and 25.32

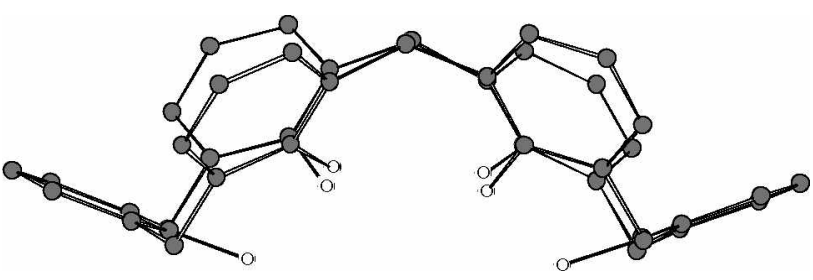

(b) cone (pinched: side view; Chem 3D)

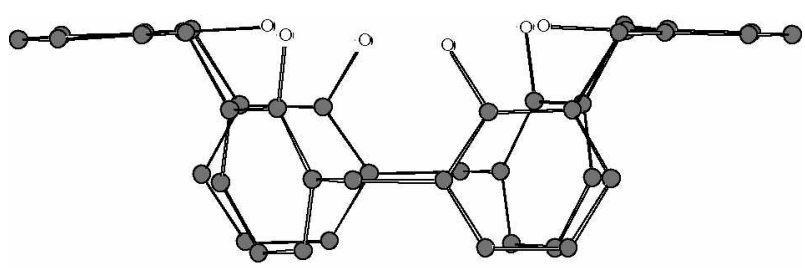

(d) cone (winged; Chem3D)

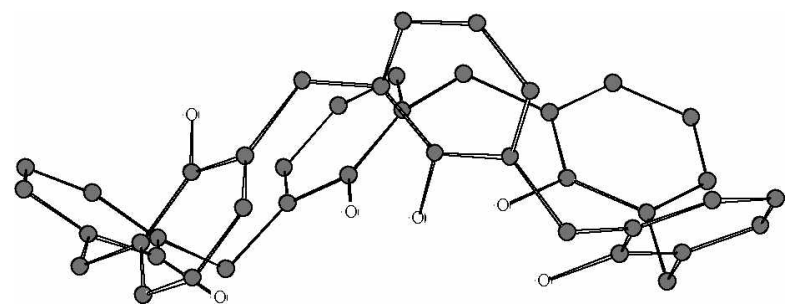

(t) partial-cone (Chem3D)

Figure 1. (continued) 


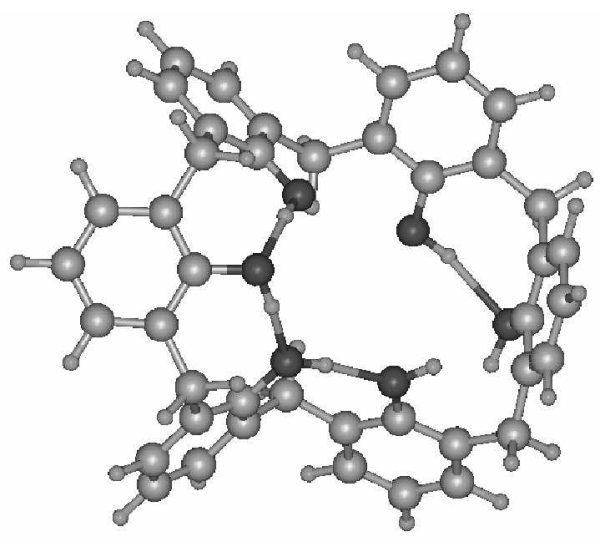

(g) 1,2-altemate (PosMol)

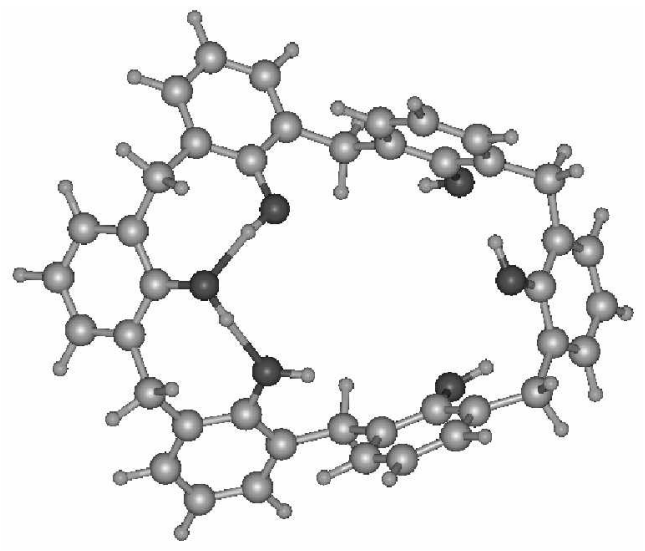

(i) 1,3-altemate (PosMol)

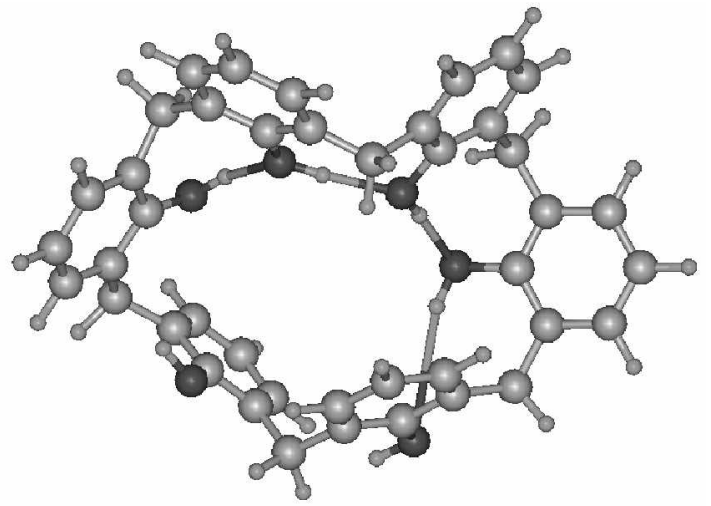

(k) l.4-altemate (PosMol)

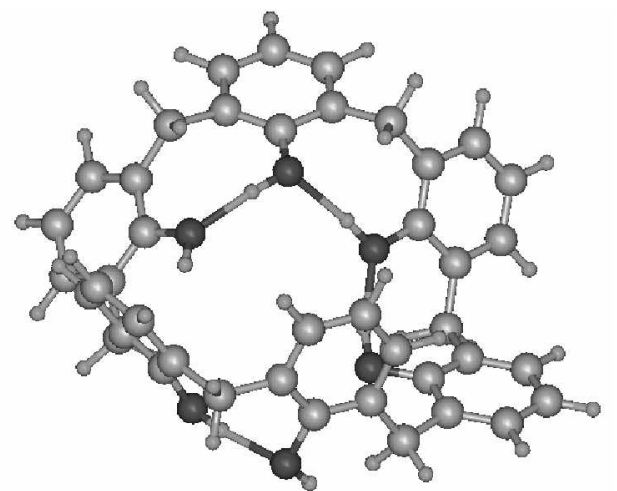

(m) 1,2,3-altemate (PosMol)

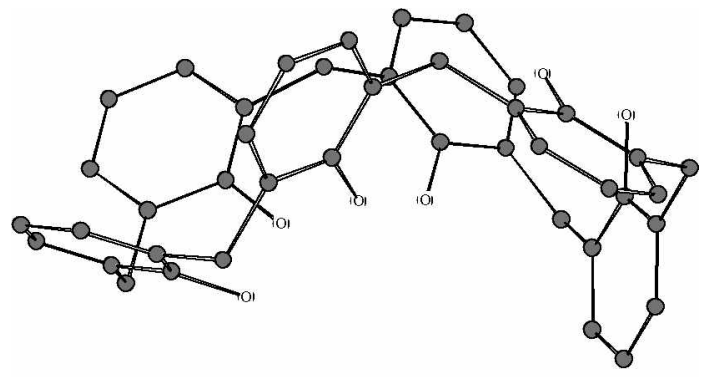

(h) 1,2-alternate (Chem3D)

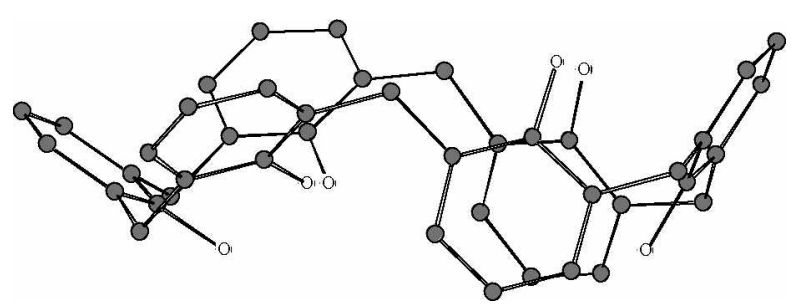

(j) 1,3-altemate (Chem3D)

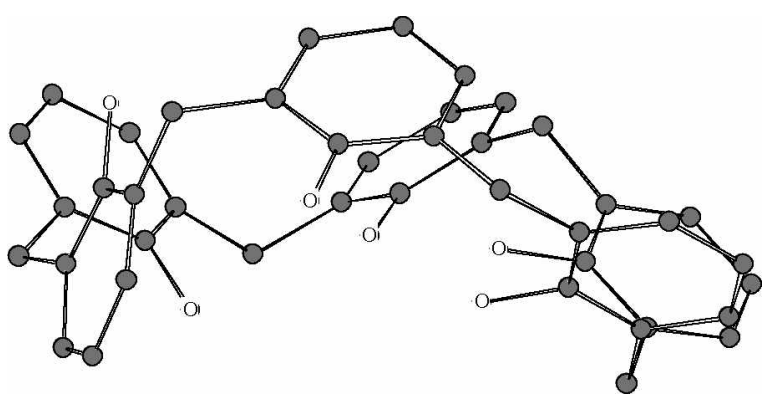

(1) 1,4-altemate (Chem31)

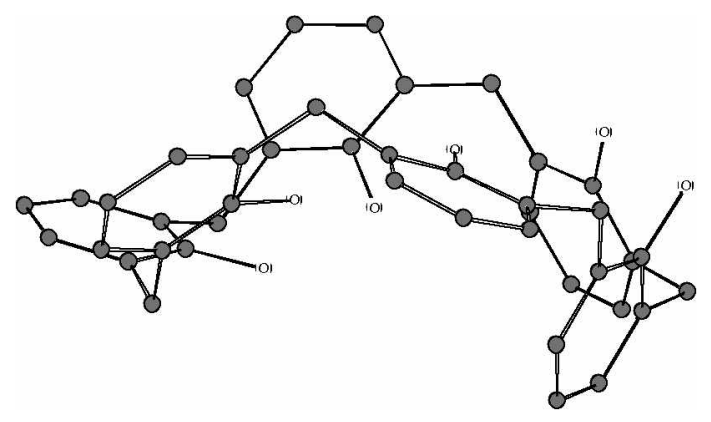

(n) 1,2,3-altemate (Chem3D)

Figure 1. (continued) 


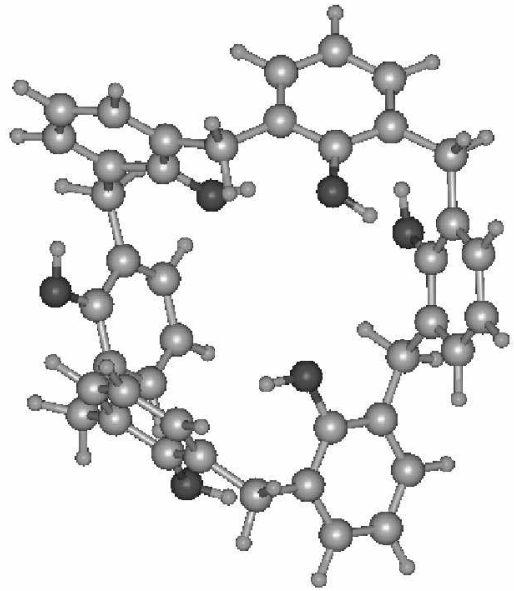

(o) $1,3,5$-altentate (PosMol)

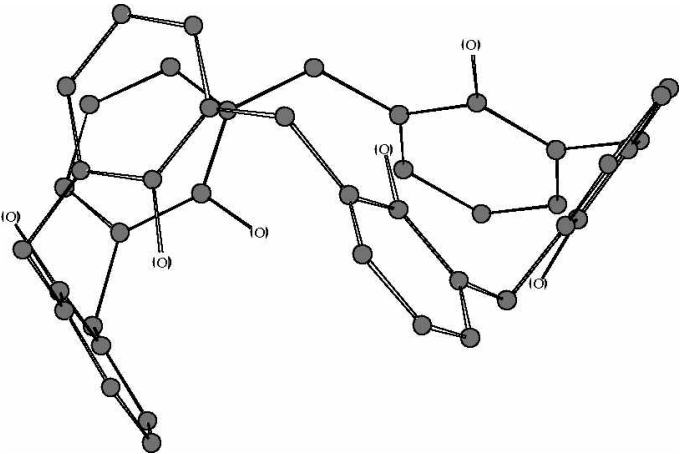

(p) $1,3,5$-alternate (Chem3D)

Figure 1. DFT B3LYP/6-31+Gid,p) optimized molecular structures of the contomers of 1 (calix[6]arene ). (a) Bottom view of the pinched cone confonmer by PosMol"s with hydrogen bonds shown, (b) side view of the pinched cone confonmer by Chem3 $3 \mathrm{D}^{20}$ without hydrogen atoms, (c) bottom view of the winged cone, (d) side view of the winged cone, (e) bottom view of the partial-cone, (f) side view of the partial-cone contonmer. (g) botton view of the 1,2-altentate, (h) side view of the 1,2-altemate, (i) bottom view of the 1,3-altenate, and (j) side view of the 1,3-altenate, $(\mathrm{k})$ bottom view of the 1,4-altemate, and (1) side view of the 1,4-altemate, $(\mathrm{m})$ bottom view of the 1,2,3-altemate, and (n) side view of the 1,2,3-altennate, $(0)$ bottom view of the 1,3,5-altemate, and ( $\mathrm{p}$ ) side view of the 1,3,5-altemate. Atoms that are within a certain distance (the bond proximate distance) from one another were automatically marked as bonded. ${ }^{19}$ Therefore, the hydrogen bonds in the figures of 1 and 2 drawn by PosMol ${ }^{19}$ are not real covalent bonds.

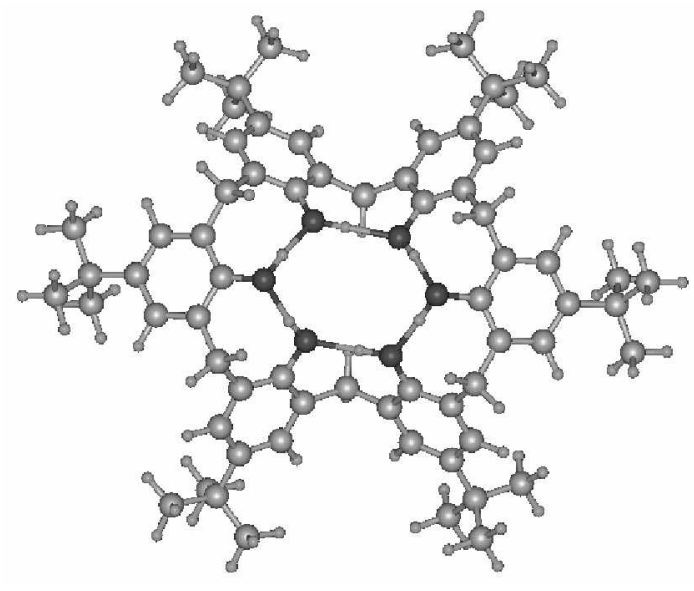

(a) cone (pinched: PosMol)

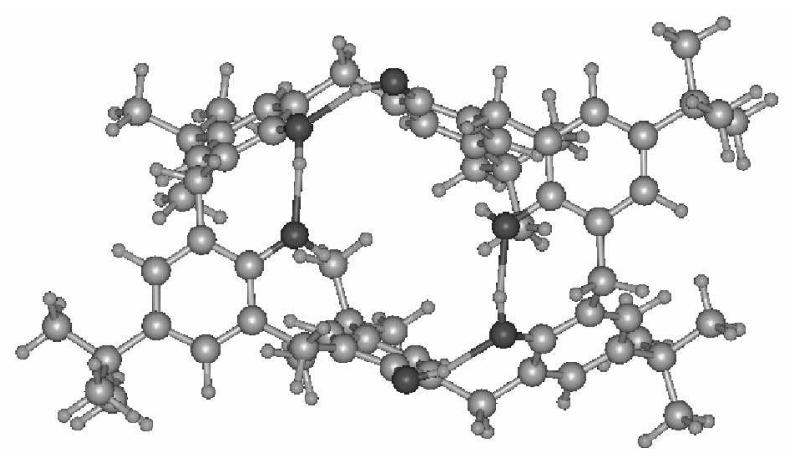

(c) cone (winged: PosMol)

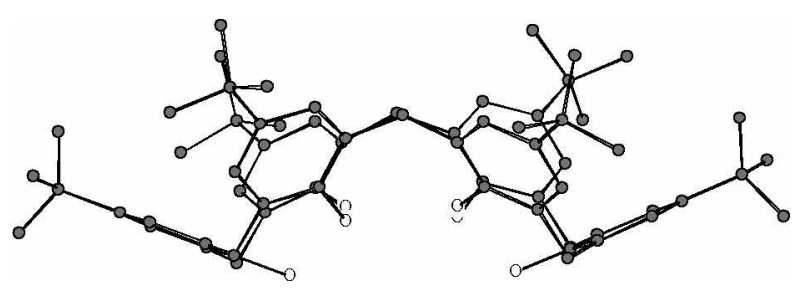

(b) cone (pinched; Chem3D)

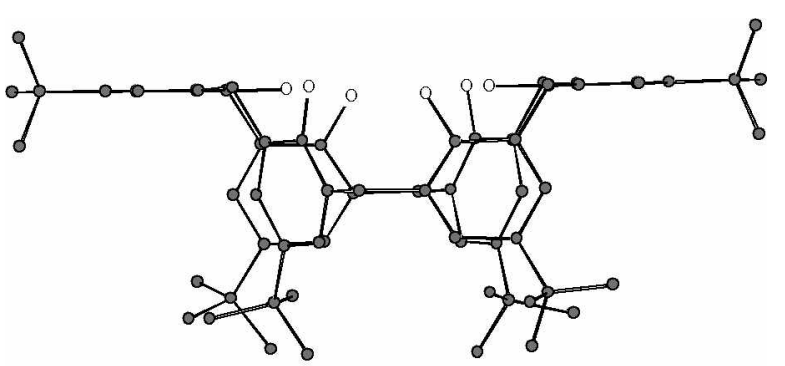

(d) cone (winged; Chem3D)

Figure 2. (continued) 


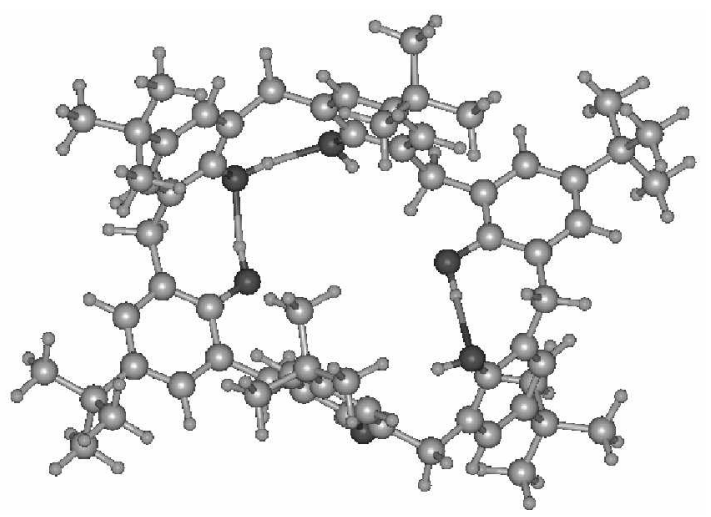

(e) partial-cone (PosMol)

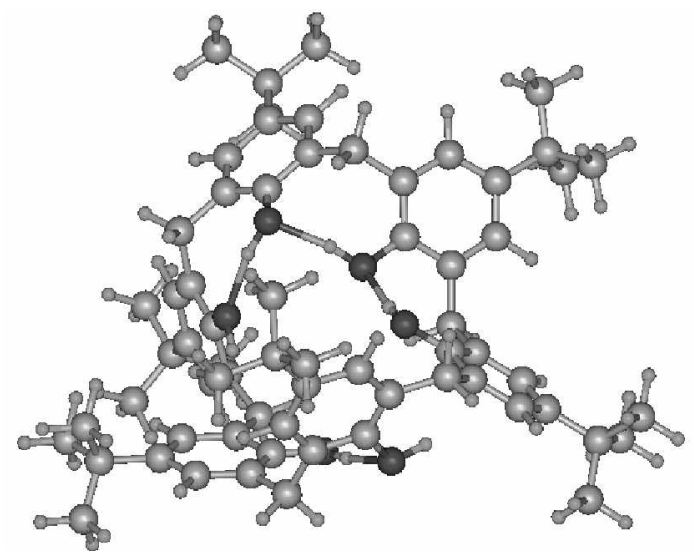

(g) 1,2-altemate (PosMol)

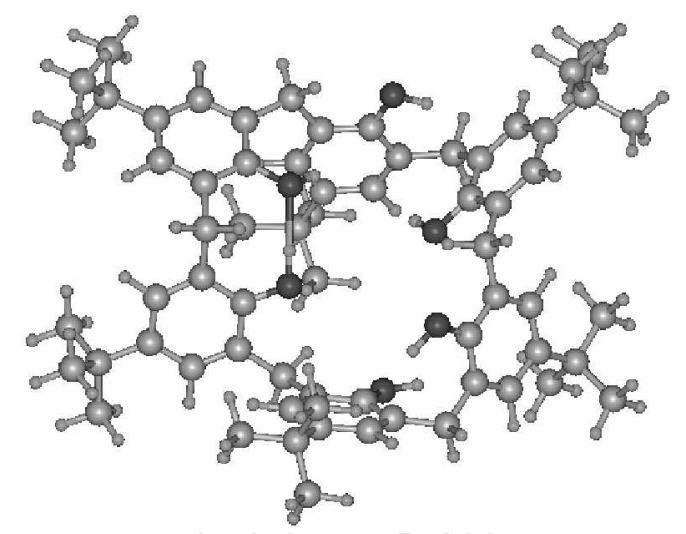

(i) 1,3-altentate (PosMol)

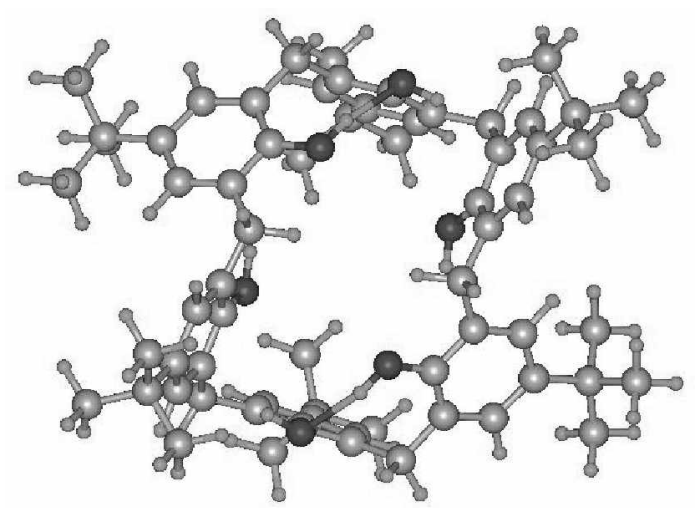

(k) l,4-alteriate (PosMol)

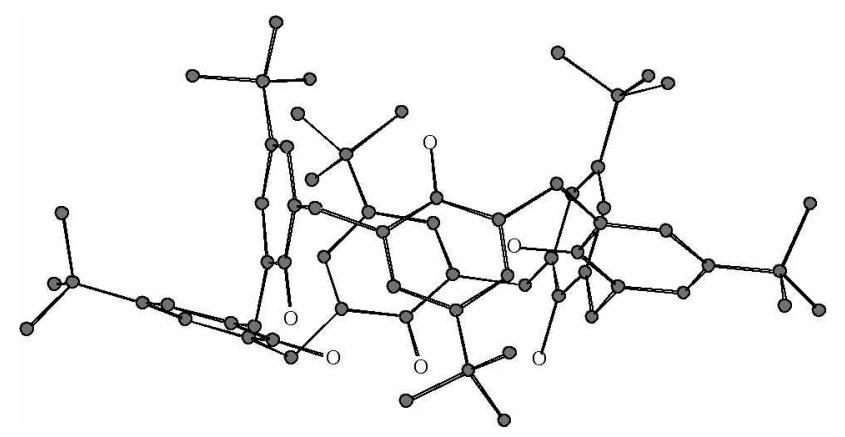

(f) partial-cone (Chem3D)

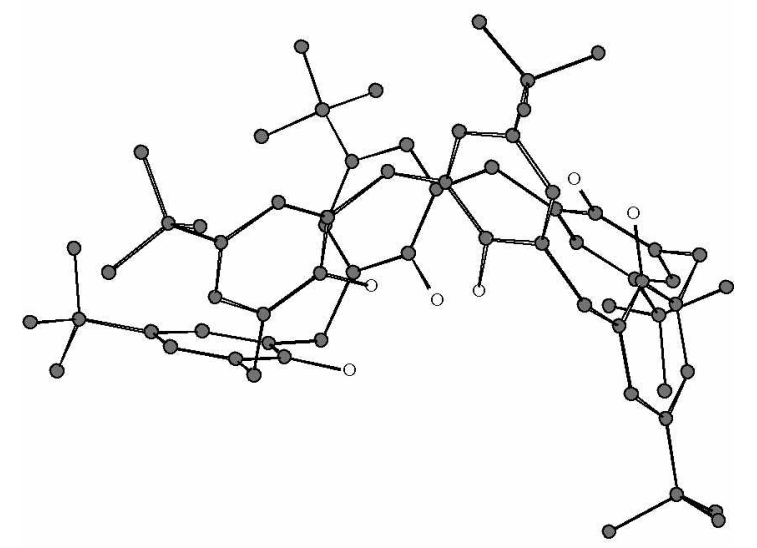

(h) 1,2-alternate (Chem3D)

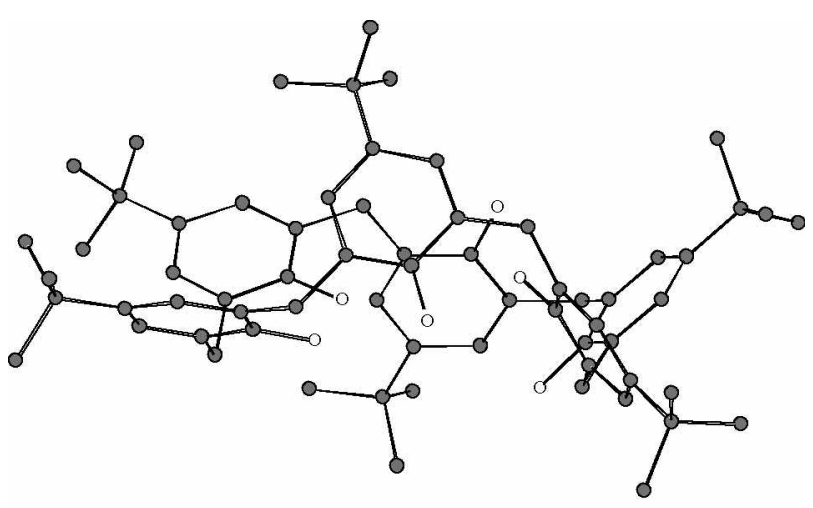

(j) 1,3-alternate (Chem3D)

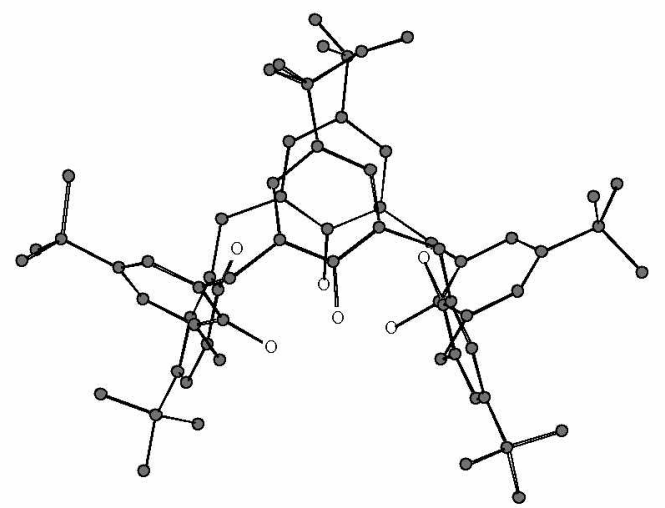

(1) 1,4-alternate (Chem3D)

Figure 2. (continued) 


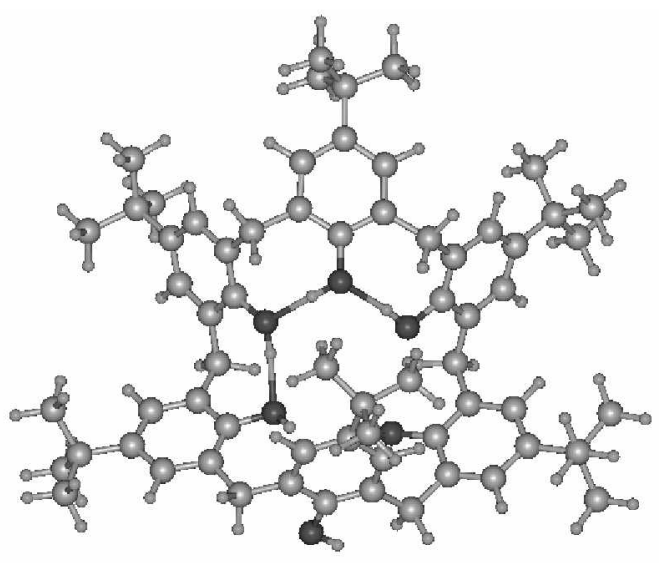

(min) $1,2,3$-altentate (PosMol)

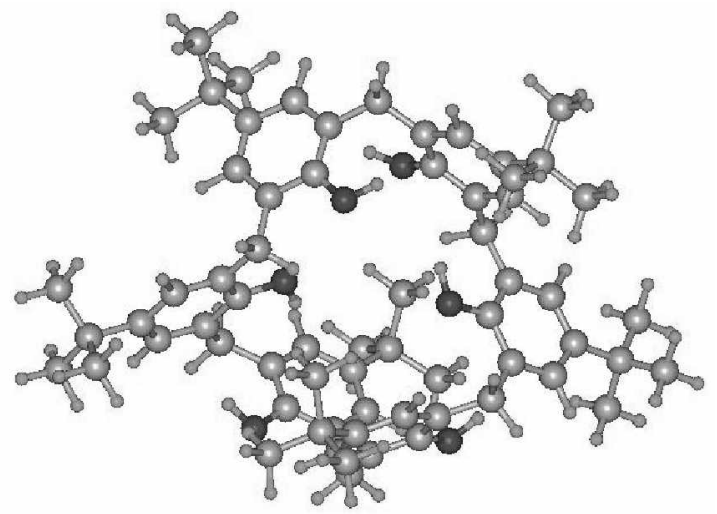

(o) 1,3,5-altenate (PosMol)

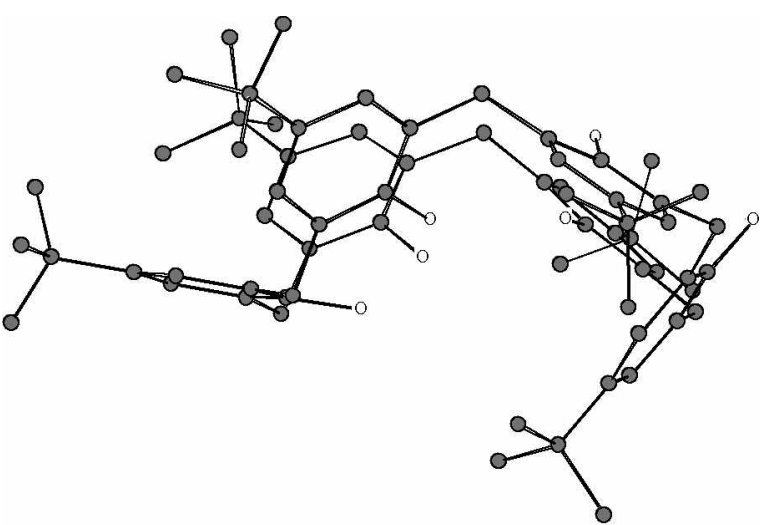

(n) 1,2,3-alternate (Chem3D)

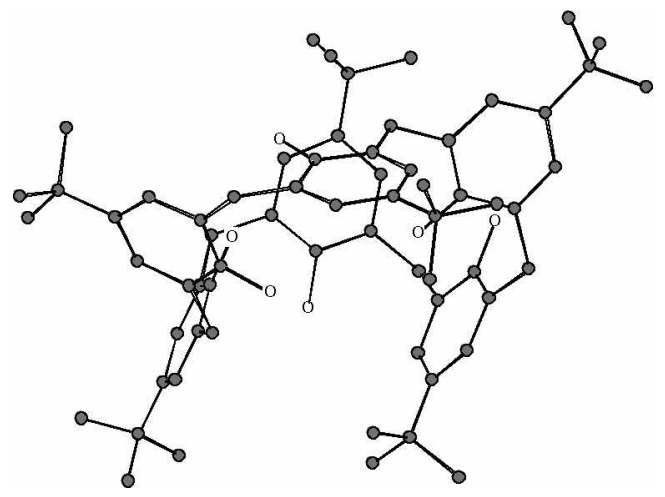

(p) $1,3,5$-alternate (Chem3L)

Figure 2. DFT B3LYP/6-3lG(d,p) optimized molecular structures of the confomers of 2 ( $p$-tent-butylcalix[6]arene). (a) Top view of the pinched cone conformer with hydrogen bonds shown, (b) side view of the pinched cone confonmer without hydrogen atoms, (c) bottom view of the winged cone, (d) side view of the winged cone, (e) top view of the partial-cone, (f) side view of the partial-cone, (g) top view of the 1,2-altemate, (h) side view of the 1,2-altemate, (i) top view of the 1,3-altemate, and (j) side view of the 1,3-alternate, $(\mathrm{k})$ bottom view of the 1,4-altemate, and (1) side view of the 1,4-altemate, $(\mathrm{m})$ bottom view of the $1,2,3$-alternate, (n) side view of the $1,2,3$-altemate, (o) bottom view of the $1,3,5$-altentate, (p) side view of the 1,3,5-alternate.

$\mathrm{kcal} / \mathrm{mol}$ more stable than 1,3-alternate, respectively. Due to the steric hindrances of $p$-tert-butyl groups of 2 . the energy differences between conformers of $\mathbf{2}$ are bigger than the values of 1 .

Figure 1 shows the DFT B3LYP/6-31+G(d.p) optimized stable structures showing hydrogen bondings of the various conformers of the calix[6]arene (1). The 1(pinched cone) (Figure 1(a)) having six hydrogen bonds is the most stable. and the conformers (partial cone, winged cone, 1.2-alternate and 1.2.3-alternate) having four hydrogen bonds are next in the order. The 1.3.5-alternate (Figure l(o)) which has no $\mathrm{H}$-bond is the least stable conformation.

Figure 2 shows the DFT B3LYP/6-31G(d.p) optimized stable structures showing hydrogen bondings of the various conformers of the tert-butylcalix[6]arene (2). The pinched cone conformer (Figure 2(a)) of 2 having six hydrogen bonds is the most stable and 2(1.2-alternate: Figure 2(g)) having four hydrogen bonds is next in the order. The steric hindrances between adjacent $p$-tert-butylbenzyl groups are not much critical in the relative stability of the various conformations of the p-tert-butylcalix[6]arene, since the cavity size made of six benzene rings are big enough. (See Chart 2 and Figure 2.) We have changed the up-down direction in the
Figures $\mathrm{l}(\mathrm{d})$ and 2(d) to show the structure better for the winged cone conformers of 1 and 2 .

Table 3 lists the DFT calculated distances and angles of intramolecular hydrogen bonds of 1 . In general. if $\mathrm{O} \cdots \mathrm{O}$ distance is less than $3.0 \AA$. one interprets that the $\left(\mathrm{O}-\mathrm{H}^{\cdots} \cdot \mathrm{O}\right)$ hydrogen bond is relatively strong for this intramolecular case. ${ }^{18}$ The $\mathrm{O} \cdots \mathrm{O}$ distances of $2.64-2.80 \mathrm{~A}$ in Table 3 suggest that these calculated values in the calix[6]arene (1) display strong hydrogen bonds.

In order to compare our calculated H-bond distances of 1 with the values of the intramolecular hydrogen bonds of $t$-butylcalix[6]arene (2), we have tabulated the DFT calculated $\mathrm{H}$-bond distances of $\mathbf{2}$ (Table 5 ). The average calculated $\mathrm{O} \cdots \mathrm{O}$ distances (2.638 $\AA$ in Table 3 and $2.640 \AA$ in Table 5) of the intramolecular hydrogen bonds of the cone conformers of calix[6]arene (1) and $t$-butylcalix[6]arene (2) are similar to the experimental crystal structure values $(2.585$ and $2.597 \AA$. respectively) in Table 4 . The calculated $\mathrm{O} \cdots \mathrm{O}$ distances $(2.71$ $\sim 2.79 \mathrm{~A}$ ) of the less stable conformations are $0.07 \sim 0.15 \mathrm{~A}$ longer than the most stable cone conformer

One usually recognizes that the $(\mathrm{O}-\mathrm{H} \cdots \mathrm{O})$ hydrogen bond is stronger if the $\left(\mathrm{O}-\mathrm{H}^{\cdots} \cdot \mathrm{O}\right)$ angle is closer to $180^{\circ}{ }^{18}$ Our calculated average $(\mathrm{O}-\mathrm{H} \cdots \mathrm{O})$ angles of $163^{\circ} \sim 171^{\circ}$ in Table 
Table 3. DFT Calculated Distances $(\AA)$ and Angles $(\mathrm{O}-\mathrm{H} \cdots \mathrm{O})$ of Intramolecular Hydrogen Bonds of 1

\begin{tabular}{|c|c|c|c|c|c|c|c|c|c|}
\hline Confonner & I H-bond & 1 & 2 & 3 & 4 & 5 & 6 & म्र & Average \\
\hline 1 (cone) & $0 \cdots 0$ & 2.637 & 2.650 & 2.632 & 2.637 & 2.650 & 2.632 & 6 & 2.640 \\
\hline \multirow[t]{3}{*}{ (pinched) } & $\mathrm{H} \cdots \mathrm{O}$ & 1.664 & 1.670 & 1.643 & 1.664 & 1.670 & 1.643 & & 1.659 \\
\hline & $\mathrm{O}-\mathrm{H}$ & 0.990 & 0.991 & 0.991 & 0.990 & 0.991 & 0.991 & & 0.991 \\
\hline & Angle $(5)$ & 166.6 & 168.9 & 1758 & 166.6 & 168.9 & 175.8 & & 170.4 \\
\hline 1 (conte) & $\mathrm{O} \cdots \mathrm{O}$ & 2.778 & 2.745 & 2.778 & 2.745 & & & 4 & 2.762 \\
\hline \multirow{3}{*}{ (y:mged) } & $\mathrm{H} \cdots \mathrm{O}$ & 1.844 & 1.822 & 1.844 & 1.822 & & & & 1.833 \\
\hline & $\mathrm{O}-\mathrm{H}$ & 0.978 & 0.978 & 0.978 & 0.978 & & & & 0.978 \\
\hline & Angle $(')$ & 158.6 & 156.0 & 158.6 & 156.0 & & & & 157.3 \\
\hline \multirow[t]{4}{*}{$1(\mathrm{pe})$} & $0 \cdots 0$ & 2.796 & 2.698 & 2.673 & 2.681 & & & 4 & 2.712 \\
\hline & $\mathrm{H} \cdots \mathrm{O}$ & 1.707 & 1.695 & 1.714 & 1.856 & & & & 1.743 \\
\hline & $\mathrm{O}-\mathrm{H}$ & 0.984 & 0.987 & 0.985 & 0.979 & & & & 0.984 \\
\hline & Angle( $\left.{ }^{\circ}\right)$ & 169.8 & 170.5 & 176.5 & 160.1 & & & & 169.2 \\
\hline \multirow[t]{4}{*}{$1(12 a)$} & $0 \cdots 0$ & 2.729 & 2.659 & 2.711 & 2.941 & & & 4 & 2.760 \\
\hline & $\mathrm{H} \cdots \mathrm{O}$ & 1.739 & 1.695 & 1.773 & 2.001 & & & & 1.802 \\
\hline & $\mathrm{O}-\mathrm{H}$ & 0.980 & 0.984 & 0.979 & 0.971 & & & & 0.979 \\
\hline & Angle $(")$ & 171.1 & 165.4 & 164.8 & 162.6 & & & & 166.0 \\
\hline \multirow[t]{4}{*}{$1(13 a)$} & $0 \cdots 0$ & 2.712 & 2.752 & 2.883 & & & & 3 & 2.782 \\
\hline & $\mathrm{H} \cdots \mathrm{O}$ & 1.751 & 1.787 & 1.961 & & & & & 1.833 \\
\hline & $\mathrm{O}-\mathrm{H}$ & 0.981 & 0.980 & 0.976 & & & & & 0.979 \\
\hline & Angle( ${ }^{\circ}$ & 165.3 & 167.9 & 156.6 & & & & & 163.3 \\
\hline \multirow[t]{4}{*}{$1(14 a)$} & $0 \cdots 0$ & 2.732 & 2.764 & & & & & 2 & 2.748 \\
\hline & $\mathrm{H} \cdots \mathrm{O}$ & 1.762 & 1.788 & & & & & & 1.775 \\
\hline & $\mathrm{O}-\mathrm{H}$ & 0.981 & 0.980 & & & & & & 0.981 \\
\hline & Angle ()$^{\circ}$ & 169.1 & 173.7 & & & & & & 171.4 \\
\hline \multirow[t]{4}{*}{$1(123 a)$} & $0 \cdots 0$ & 2.729 & 2.840 & 2.845 & 2.764 & & & 4 & 2.795 \\
\hline & $\mathrm{H} \cdots \mathrm{O}$ & 1.749 & 1.865 & 1.898 & 1.800 & & & & 1.828 \\
\hline & $\mathrm{O}-\mathrm{H}$ & 0.981 & 0.981 & 0.977 & 0.977 & & & & 0.979 \\
\hline & Angles & 174.8 & 172.6 & 162.5 & 168.3 & & & & 169.6 \\
\hline $1(135 a)$ & $0 \cdots 0$ & & & & & & & 0 & \\
\hline
\end{tabular}

Table 4. Experimental $\mathrm{O} \cdots$ O Distances $(\AA)$ of Intramolecular Hydrogen Bonds of 1 and 2

\begin{tabular}{|c|c|c|c|c|c|c|c|c|}
\hline Molecule & H-bond & 1 & 2 & 3 & 4 & 5 & 6 & $\ddot{\not}$ Average \\
\hline $1(\operatorname{con} 2)^{1 \neq 1 / 2}$ & $0 \cdots 0$ & 2.570 & 2.631 & 2.554 & 2.570 & 2.631 & 2.554 & $6 \quad 2.585$ \\
\hline$(\text { cones) })^{1 \mathrm{xr}}$ & $0 \cdots \mathrm{O}$ & 2.648 & 2.609 & 2.621 & 2.610 & 2.522 & 2.573 & $\begin{array}{ll}6 & 2.597\end{array}$ \\
\hline
\end{tabular}

3 and $166^{\circ}-171^{\circ}$ in Table 5 tell that the hydrogen bondings in the calix[6]arenes ( $\mathbf{1}$ and $\mathbf{2}$ ) are almost linear and very strong.

\section{Conclusion}

The relative stabilities of the conformers of the calix[6]arene (1) and $t$-butỵlcalix[6]arene (2) are mainly dependent upon the number and strength of the intramolecular hydrogen bonds than steric hindrance of adjacent rings. The relative stability of the various conformers of 1 is in the following order: cone (pinched: most stable) $>$ partial-cone $>$ cone $($ winged $)-1.2$-alternate $\sim 1,2,3$-altemate $>1,4$-altemate $>$ 1.3 -alternate $>1.3,5$-altemate. The pinched-cone conformers of 1 and 2 are 14.65 and $13.27 \mathrm{kcal} / \mathrm{mol}$ more stable than the winged-cones. respectively. The relative stability of the different conformers of $\mathbf{2}$ is in the following order: cone (pinched) $>1,2$-altemate $>$ cone $($ winged $)>1,4$-altemate $\sim$ partial-cone $>1.2 .3$-alternate $>1.3 .5$-altemate $>1,3$-altenate. The $D F T$ optimized average $\mathrm{O} \cdots \mathrm{O}$ distances $(2.638$ and $2.640 \AA$ ) for
Table 5. DFT Calculated Distances $(\AA)$ and Angles $\left(0-H_{\cdots} \cdots\right)$ of Intramolecular Hydrogen Bonds of 2

\begin{tabular}{|c|c|c|c|c|c|c|c|c|c|}
\hline Confonmer & I $\mathrm{H}$-bond & 1 & 2 & 3 & 4 & 5 & 6 & $+\frac{1}{x}$ & Averate \\
\hline 2 (cone) & $0 \cdots 0$ & 2.650 & 2.632 & 2.629 & 2.637 & 2.650 & 2.632 & 6 & 2.638 \\
\hline \multirow[t]{3}{*}{ (pinched) } & $\mathrm{H} \cdots \mathrm{O}$ & 1.673 & 1.644 & 1.660 & 1.664 & 1.670 & 1.643 & & 1.659 \\
\hline & $\mathrm{O} \cdot \mathrm{H}$ & 0.991 & 0.991 & 0.990 & 0.990 & 0.991 & 0.991 & & 0.991 \\
\hline & Angle $(:)$ & 167.8 & 175.1 & 164.7 & 166.6 & 168.9 & 175.8 & & 169.8 \\
\hline & $0 \cdots O$ & 2.757 & 2.729 & 2.751 & 2.730 & & & 4 & 2.742 \\
\hline \multirow{3}{*}{ (winged) } & $\mathrm{H} \cdots \mathrm{O}$ & 1.825 & 1.794 & 1.817 & 1.796 & & & & 1.808 \\
\hline & $\mathrm{O} \cdot \mathrm{H}$ & 0.980 & 0.980 & 0.980 & 0.980 & & & & 0.980 \\
\hline & Angle(s) & 157.9 & 158.6 & 158.2 & 158.3 & & & & 158.3 \\
\hline \multirow[t]{4}{*}{ 2(po) } & $0 \cdots 0$ & 2.795 & 2.767 & & & & & 2 & 2.781 \\
\hline & $\mathrm{H} \cdots \mathrm{O}$ & 1.793 & 1.827 & & & & & & 1.810 \\
\hline & $\mathrm{O}-\mathrm{H}$ & 0.980 & 0.978 & & & & & & 0.979 \\
\hline & Angle(") & 171.9 & 169.7 & & & & & & 170.8 \\
\hline \multirow[t]{4}{*}{$2(12 a)$} & $\mathrm{O} \cdots \mathrm{O}$ & 2.677 & 2.659 & 2.694 & 2.941 & & & 4 & 2.743 \\
\hline & $\mathrm{H} \cdots \mathrm{O}$ & 1.711 & 1.689 & 1.720 & 2.0011 & & & & 1.780 \\
\hline & $\mathrm{O}-\mathrm{H}$ & 0.984 & 0.987 & 0.982 & 0.971 & & & & 0.981 \\
\hline & Angle( $)$ & 166.1 & 166.5 & 170.7 & 1626 & & & & 166.5 \\
\hline \multirow[t]{4}{*}{$2(13 a)$} & $\mathrm{O} \cdots \mathrm{O}$ & 2.778 & & & & & & 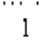 & 2.778 \\
\hline & $\mathrm{H} \cdots \mathrm{O}$ & 1.816 & & & & & & & 1.816 \\
\hline & $\mathrm{O}-\mathrm{H}$ & 0.976 & & & & & & & 0.976 \\
\hline & Angle $(")$ & 168.1 & & & & & & & 168.1 \\
\hline \multirow[t]{4}{*}{$2(1+a)$} & $0 \cdots 0$ & 2.776 & 2.769 & & & & & 2 & 2.773 \\
\hline & $\mathrm{H} \cdots \mathrm{O}$ & 1.812 & 1.8014 & & & & & & 1.808 \\
\hline & $\mathrm{O} \cdot \mathrm{H}$ & 0.978 & 0.978 & & & & & & 0.978 \\
\hline & Angle $(\vdots)$ & 167.9 & 168.3 & & & & & & 168.1 \\
\hline \multirow[t]{4}{*}{$2(123 a)$} & $0 \cdots 0$ & 2.708 & 2.679 & 2.764 & & & & 3 & 2.717 \\
\hline & $\mathrm{H} \cdots \mathrm{O}$ & 1.741 & 1.694 & 1.796 & & & & & 1.744 \\
\hline & $\mathrm{O} \cdot \mathrm{H}$ & 0.984 & 0.986 & 0.979 & & & & & 0.983 \\
\hline & Angle $(:)$ & 166.5 & 175.1 & 169.8 & & & & & 170.5 \\
\hline $2(135 a)$ & $\mathrm{O} \cdots \mathrm{O}$ & & & & & & & 0 & \\
\hline
\end{tabular}

the pinched cone conformations of 1 and 2 are sinular to the experimental distances $(2.585 \AA$ and $2.597 \AA$. respectively). Our calculated average $\left(\mathrm{O}-\mathrm{H}^{\cdots} \mathrm{O}\right)$ angles of $163^{\circ} \sim 171^{\circ}$ tell that the hydrogen bondings in the calix[6]arenes ( 1 and 2 ) are very strong.

Acknowledgments. This research was supported by the Chung-Ang University research grants in 2009. The large portions of the computations were carried out with use of the computer facilities at the Research Center for Computational Science of the Okazaki National Research Institutes in Japan.

\section{References}

1. (a) Calixanenes in Action; Mandolini, L.: Ungaro, R., Eds.; World Scientific Publishers Co.: Singapore, 2007. (b) Gutsche, C. D. Calixalenes Revisited; Royal Society of Chemistry: Cambridge, 1998 (c) Calixanenes $50^{\text {sh }}$-Amiversany: Commemorative tolume: Vicens, J.; Asfari, Z.; Harrowtield, I. M., Eds.; Kluwer Academic Publishers: Dordrecht, The Netherlands, 1991. (e) Gutsche, C. D. Calixamenes: Royal Society of Chemistry: Cambridge, 1989. (f) Calixarenes: A Versatile Class of Macrocyclic Compounds; Vicens, J; Böhmer, V., Eds.; Kluwer Academic Publishers: Dordrecht, The Netherlands, 1991

2. (a) Kanamathareddy, S.: Gutsche, C. D. J. Org. Chem. 1994, 59 , 3871. (b) Otsuka, H.: Araki, K.; Shinkai, S. J. Org. Chem. 1994. 59, 1542. (c) Neri, P.: Rocco, C.: Consoli, G. M. L.; Piattelli, M. J. Org. Chem 1993, 58, 6535. (d) Neri, $\mathrm{P}$; Foti, M.; Ferguson, G.; Gallagher, J. F.; Kaitner, B.; Pons, M; Molins, M. A.; 
Giunta, L.; Pappalardo, S. J. Am. Chem. Soc. 1992, HH, 7814. (e) Janssen, R. G.; Verboom, W: Harkema, S.; van Hummel, G. I.: Reinhoudt, D. N.: Pochini, A.: Ungaro, R.: Prados, P.; de Mendoza, I. J. Chem. Soc., Chent. Conmmut 1993, 506. (f) Tanssen, R. G.: van Duynhoven, J. P. M.; Verboom, W.; van Hunmel, G. J.: Harkema, S.; Reinhoudt, D. N. J.Am. Chem. Soc. 1996, 118, 3666. (g) Tanssen, R. G.; Verboom, W.; Reinhoudt, D. N: Casnati, A: Freriks, M: Pochini, A: Ugozolli, F.; Ungaro, R.: Nieto, P. M.: Carramolino, M.; Cuevas, F.: Prados, P. de Mendoza, J. Simthesis 1993, 380. (h) Moran, I. K.; Georgiev, E. M:; Yordanov, A. T.: Mague, J. T.: Roundhill, D. M. J. Org. Chem. 1994, 59,5990.

3. (a) Gutsche, C. D : Bauer, J. J. Am. Chem. Soc. 1985, 107,6052. (b) Lutz, B. T. G.: Astarloa, G.: van der Maas, J. H., Janssen, R. G.: Verboom. W.: Reinhoudt. D. N. Iib. Spectrosc. 1995, 10.29.

4. van Hoom, W. P.; van Veggel, F. C. T. M.; Reinhoudt, D. N. J. Org. Chem 1996, 61,7180.

5. Atwood, I. L.; Barbour, L. J.: Raston, C. L.; Sudria, I. B. N. Angew: Chent. Int Ed. 1998, 37, 981 .

6. Andretti, G. D.: Ugozzoli, F.: Casnati, A.: Ghidini, E.: Pochini, A.: Ungaro, R. Gazz. Chin. Ital. 1989, 119, 47

7. Halit, M.: Oeller, D.; Perrin, M: Thozet, A.; Penrin, R: Vicens, I.: Bourakhoudar, M. I. Inchision Phenom. 1988, 6, 613.

8. Molins, M. A.; Nieto, P. M.; Sanchez, C.; Prados, P.; de Mendoza, I.: Pons, M. J. Org. Chem. 1992, 57,6924.

9. Tan1ssen, R. G.; van Duynhoven, J. P. M: Verboon, W: van Hummel, G. J.; Harkema, S.; Reinhoudt, D. N. J. Am. Chem. Soc. $1996,118,3666$

10. Kim, K.: Park, S. T.: Choe, T-I. Bull. Korean Chem. Soc. 2008, 29 , 1893.

11. Kim, K.: Lee, S. H.: Choe, T-I. Bull Korean Chem Soc. 2008, 29 , 2152

12. (a) Cambritge Stricture Database: Cambridge Crystallographic Data Centre: Cambridge, U. K., 2008 (b) Atwood, T. L.; Barbour, L. J.; Heaven, M. W.; Raston, C. L. . Angew: Chem. 1998, 37, 981. (c) Andretti, G. D;: Ugozzoli, F; Casnati, A.; Ghidini, E.; Pochini, A.; Ungaro, R. Gazz. Chim. Ital 1989, 119, 47
13. HuperChem Release 7.5: Hypercube, Inc: Waterloo, Ontario, Canada, 2002.

14. Choe, J.-I.: Kim, K.: Chang. S.-K. Bull. Kowean Chem. Soc. 2000. 21,465 .

15. (a) Becke, A. D. J. Chem. Phws 1993, 98, 5648. (b) Lee, C: Yang, W.; Parr, R. G. Phns Rev $B$ 1988, 37,785

16. (a) Lunch. B. I.: Fast. P. L.: Harris, M: Truhlar. D. G. J. Phus. Chem A 2000, 104, 481 l. (b) Zhao, Y; Tishchenko, O.; Truhlar, D. G. J. Phys. Chent. B 2005, 109, 19046. (c) Tsuzuki, S.: Lüthi, H. P. J. Chem. Phvs 2001, 114, 3949 (d) Schreiner, P. R.; Fokin, A. A.: Pascal, R. A.: Meijere, A. Oig. Lett. 2006, 8, 3635.

17. Frisch, M. J; Trucks, G. W.; Schlegel, H. B; Scuseria, G. E; Robb, M. A.; Cheeseman, J. R.; Montgomer, Jr., I. A.; Vreven, T.; Kudin, K. N.: Burant, I. C.: Millam, J. M.; Iyengar, S. S.; Tomasi, I.: Barone, V.: Mennucei, B.: Cossi, M.: Scalmani, G.: Rega, N.; Petersson, G. A.: Nakatsulii, H.: Hada, M.; Ehara, M.; Tovota, K.; Fukuda, R.; Hasegawa, J.: Ishida, M:- Nakajima, T; Honda, Y.; Kitao, O.; Nakai, H.; Klene, M.; Li, X.; Knox, J. E.; Hratchian, H. P.; Cross, I. B.: Bakken, V.; Adamo, C.: Jaramillo, J.: Gomperts, R:; Stratmann, R. E.: Yazyev, O.: Alstin, A. I.; Cammi. R.; Pomelli, C.; Ochterski, J. W: Avala, P. Y.; Morokuma, K.; Voth, G. A.; Salvador, P.; Dannenberg, J. J.; Zakrzewski, V. G.: Dapprich, S.; Daniels, A. D.; Strain, M. C.; Farkas, O.: Malick. D. K.: Rabuck. A. D.: Raghavachari. K.: Foresman. J. B.; Ortiz, I. V.; Cui, Q.; Baboul, A. G.; Clifford, S.; Cioslowski, T.; Stefanov, B. B.; Liu, G.; Liashenko, A.; Piskorz, P.; Komaromi, I.; Martin, R. L.; Fox, D. J; Keith, T; Al-Laham, M. A.: Peng, C. Y.: Nanayakkara, A.: Challacombe, M.: Gill, P. M. W.; Johnson, B.; Chen, W.; Wong, M. W: Gonzalez, C.: Pople, I. A. Gattssion 03, Revision D.0 I; Gaussian, Inc.: Wallingford, $\mathrm{CT}, 2004$

18. (a) Teffrey. G. A An Imoduction to Hydrogen Bonding: Oxford Univ. Press: Cambridge, 1997. (b) Pak, C.; Lee, H. M.; Kim, I. C.: Kim, D.; Kim, K. S. Struct. Chem 2005, 16, 187.

19. Lee, S. J.; Chung. H. Y.; Kim, K. S. Bull. Korean Chent. Soc. $2004,25,1061$

20. Chem3D, Version 7.0; Cambridge Soft: Cambridge, MA, U.S.A., 2001 